\title{
VIABILITAS DAN AKTIVITAS BAKTERI PELARUT FOSFAT INDIGENUS PADA BEBERAPA BAHAN PEMBAWA CAIR
}

\section{VIABILITY AND ACTIVITY OF INDIGENOUS PHOSPHATE SOLUBILIZING BACTERIA ON SOME LIQIUD CARRIERS}

\author{
Eko Hary Pudjiwati ${ }^{1}$, Nuraida Binti Hamid²) \\ 1) Fakultas Pertanian, Universitas Borneo Tarakan \\ 2) Mahasiswa Fakultas Pertanian, Universitas Borneo Tarakan \\ Email: 1 inok3959@gmail.com
}

\begin{abstract}
ABSTRAK
Phosphor $(P)$ merupakan unsur yang ketersediaannya bagi tanaman tergolong rendah akibat terikat oleh unsur Al dan Fe pada tanah masam dan pada tanah basa terikat oleh unsur $\mathrm{Ca}$. Salah satu upaya untuk meningkatkan ketersediaan $\mathrm{P}$ tanah menggunakan bakteri pelarut fosfat (BPF) sebagai pupuk hayati. Kualitas pupuk hayati salah satunya ditentukan oleh jenis BPF dan bahan pembawa. Tujuan penelitian ini untuk mengetahui bahan pembawa cair yang dapat mempertahankan viabilitas dan aktivitas bakteri pelarut fosfat. Penelitian ini menggunakan Rancangan Acak Lengkap Faktorial dengan 2 perlakuan yaitu jenis bahan pembawa dan jenis isolate BPF diulang 3 kali. Jenis bahan pembawa terdiri dari Nutrien Broth (NB), air kelapa dan ekstrak tauge. Jenis isolat terdiri dari isolat $B_{5(6)}$, isolate $B_{1(17)}$ dan konsorsium isolat $\left(B_{5(6)}+B_{1(17)}\right)$. Hasil penelitian menunjukkan ketiga bahan pembawa memiliki nilai $\mathrm{pH}$ yang masuk dalam kisaran $\mathrm{pH}$ yang diperlukan BPF untuk hidup, jumlah isolate yang memenuhi baku mutu pupuk hayati dan nilai indeks kelrutan fosfat yang tergolong tingi. Rata-rata jumlah koloni BPF tunggal dan konsorsium tertinggi diperoleh pada bahan pembawa ekstrak tauge yaitu untuk isolat $B_{5(6)}$ adalah $8,5 \times 10^{10} \mathrm{CFU} / \mathrm{ml}$, isolate $B_{1(17)} 4,94 \times 10^{10} \mathrm{CFU} / \mathrm{ml}$, dan isolat $B_{5(6)}+B_{1(17)} 1,49 \times 10^{10}$ $\mathrm{CFU} / \mathrm{ml}$. Nilai rata-rata indeks kelarutan fosfat tertinggi untuk isolat $\mathrm{B}_{5(6)}$ dan konsorsium isolate $B_{5(6)}+B_{1(17)}$ dicapai pada bahan pembawa ekstrak tauge, yaitu 2,42 dan 2, 28, sedangkan untuk isolate $B_{1(17)}$ diperoleh dari bahan pembawa NB dengan nilai indeks kelarutan fosfat sebesar 2,5 .
\end{abstract}

\section{Kata Kunci: Bakteri Pelarut Fosfat, Bahan Pembawa Cair, Viabilitas}

\begin{abstract}
Phosphorous $(P)$ is an element whose availability for plants is classified as low due to being bound by $\mathrm{Al}$ and Fe elements in acid soils and in alkaline soils bound by Ca elements. One of the efforts to increase soil $P$ availability is using phosphate solubilizing bacteria (BPF) as biological fertilizer. The quality of biological fertilizers is determined by the type of BPF and the carrier material. The purpose of this study was to determine the liquid carrier material that can maintain the viability and activity of phosphate solubilizing bacteria. This study used a completely randomized factorial design with 2 treatments, namely the type of carrier material and the type of BPF isolate repeated 3 times. The types of carriers consist of Nutrient Broth (NB), coconut water and bean sprouts extract. The types of isolates consisted of isolate $B_{5(6)}$, isolate $B_{1(17)}$ and isolate consortium $\left(B_{5(6)}+B_{1(17)}\right)$. The results showed that the three carriers had $\mathrm{pH}$ values that fell within the $\mathrm{pH}$ range required by BPF to live, the number of isolates that met the biological fertilizer standards and the high phosphate solubility index value. The highest average number of single and consortium BPF colonies was obtained for the bean sprouts extract carrier material, namely isolate $B_{5(6)}$ was $8.5 \times 1010 \mathrm{CFU} / \mathrm{ml}$, isolate $B_{1(17)} 4.94 X 1010 \mathrm{CFU} / \mathrm{ml}$, and isolate $B_{5(6)}+$ $B_{1(17)} 1.49 X 1010 \mathrm{CFU} / \mathrm{ml}$. The highest mean value of phosphate solubility index for isolate
\end{abstract}


$B_{5(6)}$ and isolate consortium $B_{5(6)}+B_{1(17)}$ was achieved in the bean sprouts extract carrier material, namely 2.42 and 2, 28, while for isolate $B_{1(17)}$ was obtained of the NB carrier material with a phosphate solubility index value of 2.5.

\section{Keywords: Phosphate Solubilizing Bacteria, Liqiud Carrier Material, Viability}

\section{PENDAHULUAN}

Phosphor $(P)$ merupakan salah satu unsur hara yang dibutuhkan tanaman dalam jumlah yang relative besar, tetapi ketersedian hara ini di dalam tanah relative rendah yang disebabkan oleh proses fiksasi $P$. Menurut Wulandari (2001) pada tanah masam $P$ terikat oleh Al atau Fe membentuk $\mathrm{AlPO}_{4}$ atau $\mathrm{FePO}_{4}$, sedangkan pada tanah alkali $P$ bersenyawa dengan $\mathrm{Ca}$ atau $\mathrm{Mg}$ membentuk Ca3(PO4)2 atau Mg3(PO4)2 yaitu bentuk $P$ yang tidak tersedia bagi tanaman. Ketersediaan $P$ yang rendah dapat menyebabkan pertumbuhan tanaman terganggu dan produksinya menurun.

Pemupukan $\mathrm{P}$ untuk meningkatkan ketersediaan $\mathrm{P}$ didalam tanah tidak efisien, karena $70 \%$ sampai $90 \% \mathrm{P}$ yang diberikan ke tanah dijerap oleh koloid tanah sehingga menjadi tidak tersedia bagi tanaman (La Habi, 2018). Salah satu cara untuk meningkatkan ketersediaan $P$ tanah adalah menggunakan bakteri pelarut fosfat (BPF), yaitu kelompok bakteri yang mampu mengubah fosfat tidak larut dalam tanah menjadi bentuk yang larut. Mekanisme pelarutan fosfat di dalam tanah oleh bakteri pelarut fosfat melalui ekskresi asam-asam organik dan enzim yang dapat memutuskan fosfat yang terikat oleh senyawa organik.

Bakteri pelarut fosfat dapat digunakan sebagai pupuk hayati (biofertilizer) karena kemampuannya sebagai penyedia hara P. Kualitas pupuk hayati ditentukan oleh viabilitas dan aktivitas inokulan yang tetap terjaga selama penyimpanan. Salah satu faktor yang menentukan kualitas pupuk hayati adalah bahan pembawa. Selama masa penyimpanan pupuk hayati bahan pembawa harus mampu mempertahankan jumlah inokulan yang tinggi dan dapat menjaga keefektifan inokulan (Putri, 2010). Sifat bahan pembawa yang baik diantaranya adalah: tidak beracun, mudah untuk diproses, mudah untuk disterilkan, tersedia dalam jumlah yang memadai/murah, dan memiliki daya rekat yang baik serta harus memperhatikan ketersediaan nutrisi bagi bakteri (Wartono et al. 2012).

Pada penelitian sebelumnya diperoleh dua bakteri pelatut fosfat dari rhizosfer tanaman sawi (Pudjiwati et al., 2019) dan kedua isolat ini bersifat kompatibel. Kombinasi kedua isolat bakteri pelarut fosfat ini dapat meningkatkan $P$ total dan $P$ tersedia lebih tinggi dibanding isolate tunggalnya yaitu sebesar 465,26 ppm dan 585,95 ppm setelah 21 hari inkubasi. Masing-masing isolat bakteri pelarut fosfat juga mampu meningkatkan $P$ tersedia dibandingkan tanpa aplikasi bakteri pelarut fosfat. Isolat-isolat bakteri pelarut fosfat indigenus ini berpotensi sebagai pupuk hayati (biofertilizer), tingkat keberhasilnnya lebih tinggi karena sudah beradaptasi dengan kondisi suatu daerah

Pupuk hayati cair memerlukan bahan pembawa cair yang harus memenuhi syarat sebagai bahan pembawa yang baik. Oleh karena itu penelitian ini bertujuan untuk mengetahui bahan pembawa cair yang dapat mempertahankan viabilitas dan aktivitas bakteri pelarut fosfat.

\section{METODE PENELITIAN Alat dan Bahan}

Alat yang digunakan dalam penelitian ini diantaranya cawan petri, gelas beker, tabung erlenmayer, jarum ose, batang pengaduk, shaker, $\mathrm{pH}$ meter, vortex mixer, autoclave, gelas ukur, panci, hot plate, laminar air flow, spirtus, oven, suntikan, kertas saring, timbangan analitik, penggaris, gunting, cutter, tabung reaksi, dan botol kaca.

Bahan yang digunakan isolat $B_{5(6)}$ dan isolat $B_{1(17),}$ media nutrient broth (NB), agar-agar bubuk, aluminium foil, plastik 
JURNAL BORNEO SAINTEK

Volume 3, Nomor 2, Oktober 2020

e-ISSN 2599-3313

P-ISSN 2615-434X

wrapping, alkohol 70\%, cairan spirtus, aquades, isolat, pikovskaya agar, tauge, air kelapa, dan gula merah.

\section{Rancangan Percobaan}

Penelitian ini dilaksanakan di Laboratorium Perlindungan Tanaman, Fakultas Pertanian, Universitas Borneo Tarakan, menggunakan Rancangan Acak Lengkap (RAL) faktorial. Faktor pertama terdiri dari tiga taraf, M1 = Media NB, M2 = Media air kelapa dan M3 = Media ekstrak tauge. Faktor kedua juga terdiri dari tiga taraf, $\mathrm{B} 1=$ isolat $\mathrm{B}_{5(6)}, \mathrm{B} 2=$ isolat $\mathrm{B}_{1(17)}$ dan $\mathrm{B} 3=$ Konsorsium isolat $\left(B_{5(6)}\right)$ dan $\left(B_{1(17)}\right)$. Diperoleh 9 kombinasi perlakuan dan setiap perlakuan diulang sebanyak 3 kali maka total keseluruhan sebanyak 27 satuan percobaan.

\section{Peremajaan dan Pengayaan Isolat}

Masing-masing isolat murni bakteri pelarut fosfat ditumbuhkan pada medium NA dengan metode spread plate (cawan sebar) kemudian disimpan pada suhu ruang (Ahmad et al 2014). Pengayaan dilakukan dengan menginokulasikan isolat bakteri dari medium Nutrient Agar (NA) secara aseptik sebanyak 1 ose ke dalam labu erlenmeyer berisi $290 \mathrm{~mL}$ medium Nutriet Broth (NB) steril, kemudian diinkubasi dalam shaker pada kecepatan $150 \mathrm{rpm}$, suhu $28^{\circ} \mathrm{C}$, selama $2 \times 24$ jam

\section{Pembuatan dan Pengemasan Bahan Pembawa.}

Bahan pembawa nutrient broth dibuat dengan cara menimbang 13 gram bubuk NB (Nutrient Broth) dicampur dengan $1000 \mathrm{~mL}$ aquades steril. Pembuatan bahan pembawa air kelapa dengan cara menyaring air kelapa menggunakan kain saring kemudian mencampurkan air kelapa dengan $2 \%$ gula merah kemudian diaduk hingga homogen. Ekstrak Tauge (MET) dibuat dengan membuat larutan stok ekstrak tauge yaitu 100 gram tauge direbus dalam $500 \mathrm{~mL}$ aquades, dibiarkan mendidih sampai volume larutan menjadi setengahnya. Bahan pembawa ekstrak tauge dibuat dengan
Available online at www.jurnal.borneo.ac.id

Halaman 85-92

cara melarutkan larutan stok ekstrak tauge ke dalam aquades dengan konsentrasi 4\% (Prihantini et al. 2005).

Bahan pembawa yang telah dibuat kemudian dimasukkan sebanyak $50 \mathrm{ml}$ kedalam botol kaca steril ukuran $140 \mathrm{ml}$. Botol ditutup dengan alumunium foil dan dilapisi plastik wrap, diberi label sesuai perlakuan, selanjutnya disterilisasi menggunakan autoclave pada suhu 121 ${ }^{\circ} \mathrm{C}$ dan tekanan 1 atm selama 15 menit (Sarjiya dan Dwi 2011).

\section{Parameter Pengamatan}

Variabel yang diamati pada penelitian ini adalah pengukuran $\mathrm{pH}$ Formulasi, nilai Uji Kelangsungan Hidup (CFU), Indeks Pelarutan Fosfat (IP) selama 0, $15,30,45$, dan 60 hari inkubasi (penyimpanan).

\section{Analisa Data}

Data yang diperoleh diuji dengan $U j \mathrm{i}$ Normalitas sebagai syarat untuk Analisis Sidik Ragam. Hasil Uji Normalitas menunjukkan data tidak menyebar normal meskipun sudah dilakukan transformasi data. Oleh karena itu data dianalisis secara deskripstif dan disajikan dalam bentuk tabel dan gambar.

\section{HASIL DAN PEMBAHASAN Derajat Keasaman (pH) Formulasi Cair}

Nilai rata-rata $\mathrm{pH}$ formulasi cair dari sembilan (9) kombinasi bahan pembawa dan jenis isolat disajikan pada Tabel 1 . Selama penelitian terlihat bahwa nilai rata-rata $\mathrm{pH}$ formulasi secara umum menunjukkan peningkatan dan puncaknya terjadi pada 45 hari penyimpanan, setelah itu terjadi penurunan pada 60 hari penyimpanan. Perubahan $\mathrm{pH}$ terjadi karena aktivitas bakteri pelarut fosfat yang merubah senyawa organik di dalam bahan pembawa. $\mathrm{pH}$ formulasi cair biofertilizer harus stabil pada kisaran nilai pH optimal, karena akan mempengaruhi viabilitas dan aktivitas inokulum (Pindi dan Satyanarayana, 2012). 
Tabel 1. Nilai pH Formulasi Cair

\begin{tabular}{lcccccc}
\hline \multirow{2}{*}{ Perlakuan } & \multicolumn{5}{c}{ Lama Penyimpanan } & Rata-rata \\
\cline { 2 - 6 } & 0 hari & 15 hari & 30 hari & 45 hari & 60 hari & \\
\hline M1B1 & 6,48 & 7,05 & 7,72 & 9,78 & 9,05 & 8,02 \\
M1B2 & 6,51 & 7,25 & 7,95 & 9,94 & 8,59 & 8,05 \\
M1B3 & 6,56 & 7,15 & 7,98 & 10,13 & 9,33 & 8,23 \\
M2B1 & 5,34 & 4,79 & 5,38 & 6,39 & 5,61 & 5,50 \\
M2B2 & 5,35 & 5,76 & 6,16 & 7,57 & 6,38 & 6,25 \\
M2B3 & 5,37 & 5,24 & 5,33 & 7,18 & 5,64 & 5,75 \\
M3B1 & 6,51 & 7,12 & 8,83 & 9,55 & 9,14 & 8,23 \\
M3B2 & 6,42 & 7,46 & 9,06 & 9,54 & 9,03 & 8,30 \\
M3B3 & 6,27 & 7,42 & 8,83 & 9,52 & 9,01 & 8,21 \\
\hline
\end{tabular}

Nilai kisaran $\mathrm{pH}$ formulasi cair biofertilizer pada semua perlakuan masih memenuhi $\mathrm{pH}$ yang diperlukan oleh bakteri pelarut fosfat untuk hidup yaitu kisaran pH 4 - 10,6 Simanungkalit et al., 2006). Nilai rata-rata $\mathrm{pH}$ formulasi selama penyimpanan menunjukkan formulasi dengan bahan pembawa ekstrak tauge paling tinggi diikuti nutrient broth dan paling rendah adalah air kelapa. Setiap bahan pembawa memiliki komposisi dan jumlah kandungan senyawa organik yang berbeda-beda. Hal ini menyebabkan perbedaan nilai $\mathrm{pH}$ selama masa penyimpanan meskipun dengan pola perubahan yang hampir sama. Turunnya nilai $\mathrm{pH}$ pada 60 hari penyimpanan disebabkan asam organik yang terakumulasi yang dihasilkan oleh bakteri.

\section{Viabiltas Bakteri Pelarut Fosfat}

Bahan pembawa yang baik harus dapat menjaga viabilitas (jumlah koloni) Bakteri Pelarut Fosfat selama masa penyimpanan. Data rata-rata jumlah koloni setiap isolat BPF pada bahan pembawa yang berbeda disajikan pada Gambar 1.

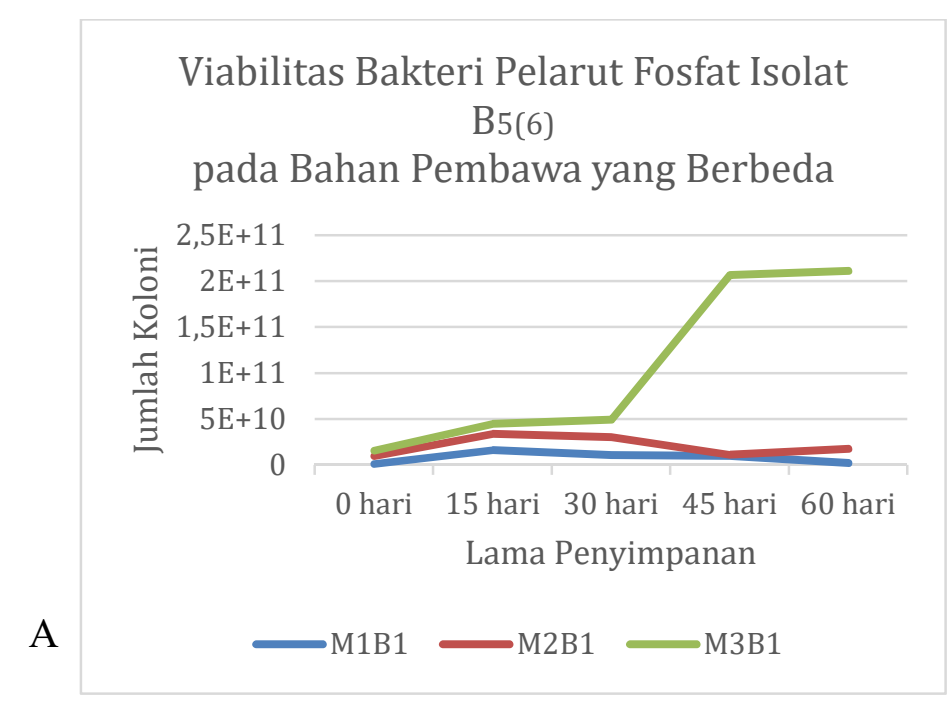




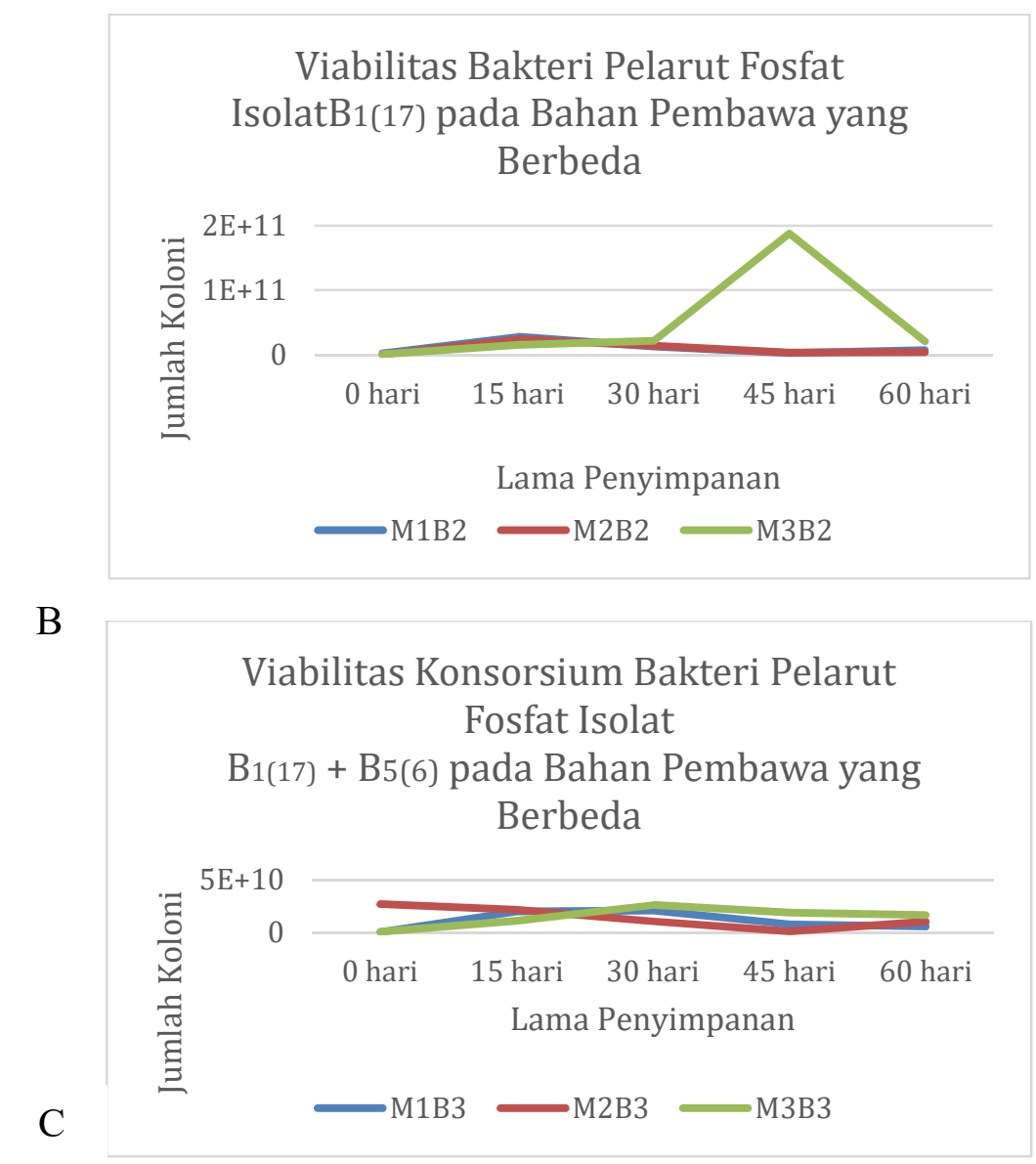

\section{Gambar 1. Jumlah Koloni BPF Isolate Tunggal dan Konsorsium Pada Tiga Bahan Pembawa}

Berdasarkan Gambar 1 terlihat bahwa jumlah koloni bakteri selama masa simpan menunjukkan pola yang berbeda pada bahan pembawa yang berbeda. Gambar 1 (A) menunjukkan jumlah koloni isolat B5(6) lebih tinggi pada bahan pembawa ekstrak tauge dibandingkan dengan dua bahan pembawa lainnya selama masa simpan. Jumlah koloni isolat ini pada akhir pengamatan mencapai $1,93 \times 10^{11}$ $\mathrm{CFU} / \mathrm{ml}$. Isolat $\mathrm{B} 1(17)$ menunjukkan jumlah koloni dengan pola yang hampir sama pada bahan pembawa NB dan air kelapa, sedangkan pada bahan pembawa ekstrak tauge jumlah koloni tertinggi terjadi pada umur 45 hari penyimpanan dan menurun pada umur 60 hari penyimpanan (Gambar 1 (B)). Pada perlakuan B3 yaitu konsorsium BPF $\mathrm{B} 1(17)+\mathrm{B} 5(6)$ yang diinokulasikan pada bahan pembawa yang berbeda terlihat jumlah koloni selama penyimpanan menunjukkan pola yang berbeda-beda (Gambar 1(C)). Secara umum bahan pembawa yang memberikan nilai ratarata jumlah koloni tertinggi pada isolat tunggal maupun konsorsium adalah ekstrak tauge. Rata-rata jumlah koloni pada bahan pembawa ekstrak tauge untuk isolat $B_{5(6)}$ adalah $8,5 \times 10^{10}$ $\mathrm{CFU} / \mathrm{ml}$, isolate $B_{1(17)} 4,94 \times 10^{10} \mathrm{CFU} / \mathrm{ml}$, dan isolat $B_{5(6)}+B_{1(17)} 1,49 \times 10^{10} \mathrm{CFU} / \mathrm{ml}$. Jumlah koloni isolate tunggal dan konsorsium pada semua bahan pembawa dalam penelitian ini selama 60 hari masa simpan masih memenuhi syarat baku mutu jumlah koloni pada biofertilizer. Peraturan Menteri Pertanian No. 70/Permentan/SR.140/10/2011 tentang pupuk organik, pupuk hayati dan pembenah tanah, menyatakan syarat teknis jumlah koloni dalam pupuk hayati untuk bakteri dengan jenis bahan 
JURNAL BORNEO SAINTEK

Volume 3, Nomor 2, Oktober 2020

e-ISSN 2599-3313

P-ISSN 2615-434X

pembawa berupa formula cair adalah $\geq 10^{8} \mathrm{CFU} / \mathrm{ml}$. Kepadatan sel BPF yang tinggi dalam formulasi pupuk hayati diharapkan dapat mendominasi daerah perakaran pada saat diaplikasikan, sehingga mampu bersaing dengan mikroorganisme lain yang ada di dalam tanah.

Pertumbuhan koloni bakteri pada suatu bahan pembawa tergantung pada jenis isolat dan kondisi bahan pembawa seperti $\mathrm{pH}$ dan nutrisi yang terkandung di dalam bahan pembawa (Rohmah et al., 2016). Pada penelitian ini $\mathrm{pH}$ bahan pembawa selama penelitian berada dalam kisaran pH untuk BPF dapat hidup dtunjukkan dengan jumlah koloni yang tinggi. Sumber karbon di dalam bahan pembawa digunakan sebagai sumber energi bagi bakteri untuk pertumbuhannya. Hasil penelitian ini berbeda dengan penelitian Yelti et al. (2014) dimana jumlah koloni tertinggi diperoleh dari bahan pembawa air kelapa. Perbedaan hasil ini disebabkan perbedaan isolat BPF yang digunakan dan jenis kelapa yang digunakan.
Available online at www.jurnal.borneo.ac.id

Halaman 85-92
Aktivitas Pelarutan Fosfat

Aktivitas BPF dalam formulasi biofertilizer harus tetap terjaga selama masa penyimpanan, agar saat diaplikasikan tetap efektif dalam melarutkan fosfat terikat menjadi bentuk fosfat yang tersedia bagi tanaman. Pada penelitian ini aktivitas pelarutan fosfat yang dinilai dari indeks kelarutan fosfat ditampilkan pada Gambar 2. Nilai indeks kelarutan fosfat selama masa penyimpanan 60 hari untuk setiap isolat BPF pada berbagai bahan pembawa berfluktuasi. Isolat $B_{5(6)}$ menunjukkan nilai indeks kelarutan fosfat yang agak stabil pada bahan pembawa air kelapa (Gambar 2(A)), isolate $B_{1(17)}$ dan konsorsium isolat memiliki nilai indeks kelarutan fosfat lebih stabil pada bahan pembawa NB (Gambar 2 (B dan C)). Secara umum nilai indeks kelarutan fosfat pada semua perlakuan menunjukkan kisaran nilai 2,15 - 2,59, menurut Ruwanandi et al., 2014 nilai indeks kelarutan fosfat pada kisaran tersebut tergolong tinggi.

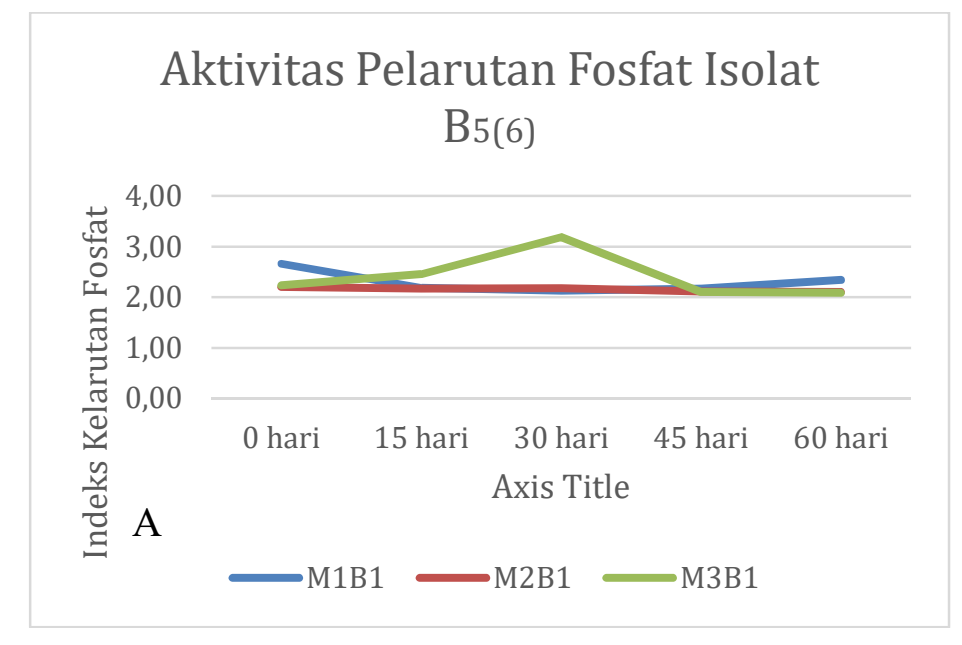



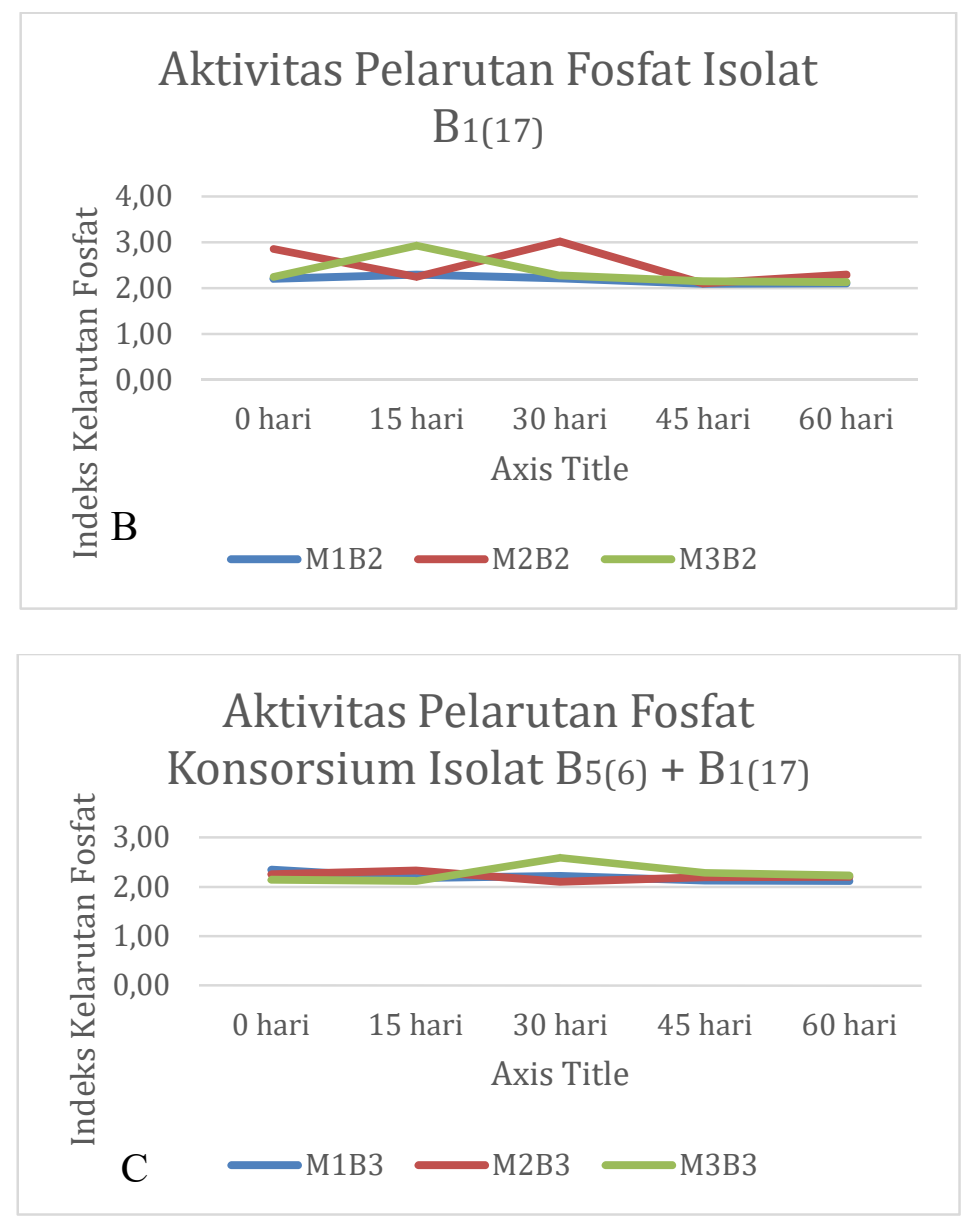

\section{Gambar 2. Aktivitas Pelarutan Fosfat BPF Isolate Tunggal dan Konsorsium Pada Tiga Bahan Pembawa}

Berdasarkan nilai rata-rata indeks kelarutan fosfat selama 60 hari penyimpanan, isolate $B_{5(6)}$ menunjukkan nilai tertinggi pada bahan pembawa ekstrak tauge yaitu $2,42 \%$, isolate $\mathrm{B}_{1(17)}$ memiliki nilai rata-rata tertinggi pada bahan pembawa NB sebesar 2,5\%, dan nilai rata-rata konsorsium isolate tertinggi $(2,28 \%)$ diperoleh pada bahan pembawa ekstrak tauge. Nilai indeks kelarutan fosfat menunjukkan kemampuan BPF dalam melarutkan fosfat, semakin tinggi nilai indeks kelarutan fosfat semakin tinggi pula kemampuan BPF dalam melaritkan fosfat. Aktivitas pelarutan fosfat BPF selama masa penyimpanan dipengaruhi oleh kemampuan BPF untuk beradaptasi pada bahan pembawa dan kondisi penyimpanan. BPF yang mampu beradaptasi akan tumuh dengan baik dan dapat melakukan aktivitasnya dengan baik.

\section{KESIMPULAN}

Ekstrak tauge, air kelapa dan NB pada penelitian ini memenuhi syarat sebagai bahan pembawa isolate BPF baik tunggal maupun konsorsium, karena memberikan nilai $\mathrm{pH}$ yang memenuhi syarat hidup BPF, menjaga viabilitas dan aktivitas BPF ditunjukkan dengan jumlah koloni BPF yang lebih tinggi dari baku mutu pupuk hayati dan nilai indeks kelarutan fosfat tergolong tinggi. Ratarata jumlah koloni BPF tunggal dan konsorsium tertinggi diperoleh pada bahan pembawa ekstrak tauge yaitu untuk isolat $\mathrm{B}_{5(6)}$ adalah $8,5 \times 10^{10}$ $\mathrm{CFU} / \mathrm{ml}$, isolate $B_{1(17)} 4,94 \times 10^{10} \mathrm{CFU} / \mathrm{ml}$, dan isolat $B_{5(6)}+B_{1(17)} 1,49 \times 10^{10} \mathrm{CFU} / \mathrm{ml}$. Nilai rata-rata indeks kelarutan fosfat tertinggi untuk isolat $B_{5(6)}$ dan konsorsium isolate $B_{5(6)}+B_{1(17)}$ dicapai pada bahan pembawa ekstrak tauge, yaitu 2,42 dan 2, 28, sedangkan untuk isolate $\mathrm{B}_{1(17)}$ diperoleh dari bahan 
JURNAL BORNEO SAINTEK

Volume 3, Nomor 2, Oktober 2020

e-ISSN 2599-3313

P-ISSN 2615-434X

pembawa NB dengan nilai indeks kelarutan fosfat sebesar 2,5.

\section{UCAPAN TERIMA KASIH}

Penelitian ini dilaksanakan dengan menggunakan dana DIPA Universitas Borneo Tarakan, oleh karena itu penulis mengucapkan terimakasih kepada Rektor Universitas Borneo dan Kepala LPPM Universitas Borneo Tarakan.

\section{DAFTAR PUSTAKA}

Ahmad A, Lolita ES, dan Zaenal A. 2014. Uji Carrier Bakteri Pelarut Fosfat sebagai Agen Pupuk Hayati. Crop Agro 7(1): 2-3

La Habi M, Jeanne IN, Dessy M, dan Marthin AK. 2018. Ketersediaan Fosfat, Serapan Fosfat, dan Hasil Tanaman Jagung (Zea mays L.) Akibat Pemberian Kompos Granul Ela Sagu Dengan Pupuk Fosfat Pada Inceptisols. Agrologia 7 (1): 42-52.

Pindi, P. K., dan S. D.V. Satyanarayana. 2012. Liquid Microbial Consortium A Potential Tool for Sustainable Soil Health. Journal of Biofertilizer and Biopesticides 3: $4 . \quad$ DOI: 10.4172/2155-6202.1000124.

Prihantini NH, Putri B, dan Yuliati R. 2005. Pertumbuhan Chlorella sp. dalam Medium Ekstrak Tauge (MET) dengan Variasi pH Awal. Makara, Sains, IX (1): 1-6.

Pudjiwati EH, Siti Z, dan Dewi S. 2019. Isolasi dan Karakterisasi Rhizobakteri yang Berpotensi sebagai Agen Pemacu Pertumbuhan Tanaman. Jurnal Borneo Saintek 2(2): 1-10.

Putri SM, Iswandi A, Fahrizal $H$, dan Ania C. 2010. Viabilitas Inokulan dalam Bahan Pembawa Gambut, Kompos, Arang Batok dan Zeolit yang Disteril dengan Iradiasi Sinar Gamma Co-60 dan Mesin Berkas Elektron. Jurnal Tanah dan Lingkungan 12(1): 23-30.

Rohmah N, Wirdhatul M, dan Tutik N. 2016. Pengaruh Kombinasi Media
Available online at www.jurnal.borneo.ac.id Halaman 85-92

Pembawa Pupuk Hayati Bakteri Penambat Nitrogen Terhadap $\mathrm{pH}$ dan Unsur Hara Nitrogen dalam Tanah. Jurnal Sains dan Seni ITS. 4(1): 2337-3520.

Ruwandani, M.N. Rakhmawati, A. dan Yulianti E. 2014. Isolasi, Karakterisasi, dan Identifikasi Bakteri Pelarut Fosfat dari Guano di Gua Anjani, Jawa Tengah. [Skripsi]. Yogyakarta. Fakultas Matematika dan Ilmu Pengetahuan Alam Universitas Negeri Yogyakarta. Yogyakarta.

Sarjiya A, Dwi A. 2011. Effects of biofertilizer containing microbial of $\mathrm{N}$-fixer, $\mathrm{P}$ solubilizer and plant growth factor producer on cabbage (Brassica oleraceae Var. Capitata) growth and soil enzymatic activities: A green house trial. Cibinong: Research Center for Biology - Indonesian Institut of Science.

Simanungkalit RDM, Suriadikarta DA, Sarawati R, Setyorini, dan Hartatik. 2006. Pupuk Organik dan Pupuk Hayati. Bogor: Balai Besar Penelitian dan Pengembangan Sumber Daya Lahan Pertanian.

Wartono, Suryadi Y, \& Susilowati DN. 2012. Keefektifan formulasi bakteri Burkholderia cepacia isolat E76 terhadap Rhizoctonia solani Kühn pada pertumbuhan tanaman padi di laboratorium. Jurnal Agrotropika 17(2): 39-42.

Wulandari, S. 2001. Efektifitas Bakteri Pelarut Fosfat Pseudomonas sp. Terhadap Pertumbuhan Tanaman Kedelai (Glycine max L.) pada Tanah Podsolik Merah Kuning. Jurnal Natur Indonesia 4(1): 21-25.

Yelti SN, Delita Z, dan Bernadeta LF, 2014 : Formulasi Biofertilizer Cair Menggunakan Bakteri Pelarut Fosfat Indigenus Asal Tanah Gambut Riau, JOM FMIPA 1(2): 651-662. 